\title{
Local Recurrence after Breast-Conserving Surgery and Mastectomy Following Neoadjuvant Chemotherapy for Locally Advanced Breast Cancer - a Meta-Analysis
}

\author{
Xiaodong Zhou ${ }^{\text {a }}$ Yujie Li ${ }^{\mathrm{b}}$ \\ a Department of Surgical Oncology, Yuyao People's Hospital, Yuyao, China; \\ ${ }^{b}$ Department of Surgical Oncology, Ningbo No. 2 Hospital, Ningbo, China
}

\begin{abstract}
Keywords
Breast-conserving surgery - Mastectomy .

Neoadjuvant chemotherapy .

Locally advanced breast cancer - Meta-analysis
\end{abstract}

\section{Summary}

Background: Breast-conserving surgery (BCS) in patients with large tumors shrunk by neoadjuvant chemotherapy (NCT) remains controversial. We conducted a meta-analysis to evaluate the local recurrence rates in locally advanced breast cancer ( $L A B C$ ) patients receiving NCT comparing BCS with mastectomy. Methods: Pubmed, Web of Knowledge, and Ovid's database were searched for studies concerning treatment for LABC from January 2000 to June 2015. A meta-analysis was performed to compare the recurrence rates of patients receiving BCS versus mastectomy following NCT. Results: 8 trials with a total of 3,215 patients were analyzed. The prevalence of local recurrence was $9.2 \%$ in the BCS group versus $8.3 \%$ in the mastectomy group without significant difference (odds ratio (OR) 1.07, 95\% confidence interval (CI) $0.28-1.48 ; p=0.66)$. The 5 -year local recurrence-free survival (LRFS) rate was lower in the mastectomy group than in the BCS group, but no significant difference was found between the 2 groups (OR 1.11, 95\% Cl 0.61-1.99; $p=0.74)$. Conclusion: BCS after NCT is safe in terms of local recurrence and LRFS in LABC women. Shrinking tumors with NCT provides the opportunity to apply BCS with no detriment to outcome.

(C) 2016 S. Karger GmbH, Freiburg

\section{Introduction}

Neoadjuvant chemotherapy (NCT) is regarded as the standard treatment for locally advanced breast cancer (LABC). NCT is widely accepted since it was shown that it can downstage the disease and allow for breast-conserving surgery (BCS) to be performed in LABC patients who are initially candidates for mastectomy or inoperable [1-3]. Furthermore, operable breast cancer patients treated with preoperative or postoperative chemotherapy had equivalent overall survival (OS) as well as increased rates of BCS following preoperative chemotherapy $[4,5]$. Therefore, BCS with improved cosmesis and quality of life is possible, even in patients with LABC [6-8].

Some studies investigating BCS after NCT have indicated locoregional recurrence rates of less than $10 \%[9,10]$. Moreover, Kuerer et al. [11] reported better disease-free survival and OS in patients with LABC undergoing BCS post NCT. However, other series have reported locoregional recurrence rates for such patients of over $20 \%$ [12, 13]. Furthermore, those studies showing better survival rates in patients with LABC undergoing BCS after NCT as compared to mastectomy might have some selection bias because the BCS groups likely included patients who achieved a good response to chemotherapy.

In consideration of the current controversy regarding BCS in patients with $\mathrm{LABC}$, the local recurrence rate was compared between $\mathrm{LABC}$ patients who underwent BCS versus mastectomy after NCT with the aim to assess the oncologic safety of NCT in LABC patients.

\section{KARGER}

(C) 2016 S. Karger GmbH, Freiburg

Fax +497614520714 
Table 1. Overview of the reviewed studies: patient demographics

\begin{tabular}{|c|c|c|c|c|c|c|c|c|c|}
\hline $\begin{array}{l}\text { Author, } \\
\text { year [ref.] }\end{array}$ & Country & Patients, $\mathrm{n}$ & Patient source & $\begin{array}{l}\text { Mean age, } \\
\text { years }\end{array}$ & $\begin{array}{l}\text { Tumor type, } \\
\%\end{array}$ & $\begin{array}{l}\text { Mean initial } \\
\text { tumor } \\
\text { diameter, cm }\end{array}$ & $\begin{array}{l}\text { Tumor } \\
\text { diameter } \\
\text { after NCT, cm }\end{array}$ & Stage, \% & $\begin{array}{l}\text { Lymph node } \\
\text { involvement, \% }\end{array}$ \\
\hline $\begin{array}{l}\text { Cho JH, } \\
2013 \text { [29] }\end{array}$ & Korea & 431 & $\begin{array}{l}\text { Severance } \\
\text { Hospital }\end{array}$ & $\begin{array}{l}\text { BCS: } 46.6 \\
\text { M: } 47.65\end{array}$ & $\begin{array}{l}\text { ductal: } 94.7 \\
\text { lobular: } 1.5 \\
\text { other: } 4.0\end{array}$ & - & - & $\begin{array}{l}\text { BCS: } \\
\text { 0-II: } 77.4 \\
\text { III: } 22.6 \\
\text { M: } \\
0-\text { II: } 67.4 \\
\text { III: } 32.6\end{array}$ & - \\
\hline $\begin{array}{l}\text { Debled M, } \\
2015 \text { [30] }\end{array}$ & France & 152 & $\begin{array}{l}\text { Institut } \\
\text { Bergonie, } \\
\text { Bordeaux }\end{array}$ & $\begin{array}{l}\text { BCS: } 49 \\
\text { M: } 51\end{array}$ & $\begin{array}{l}\text { ductal: } 96.7 \\
\text { lobular: } 3.3\end{array}$ & $\begin{array}{l}\text { BCS: } 4.5 \\
\text { M: } 7.0\end{array}$ & - & - & - \\
\hline $\begin{array}{l}\text { Eugene } \mathrm{H} \text {, } \\
\qquad 2006 \text { [31] }\end{array}$ & USA & 815 & $\begin{array}{l}\text { University } \\
\text { of Texas }\end{array}$ & - & - & - & - & $\begin{array}{l}\text { BCS: } \\
\text { I: } 4 \\
\text { II: } 58 \\
\text { III: } 38 \\
\text { M: } \\
\text { II: } 17 \\
\text { III: } 83\end{array}$ & $\begin{array}{l}\text { BCS: } 15 \\
\text { M: } 31\end{array}$ \\
\hline $\begin{array}{l}\text { Fitzal F, } \\
\quad 2010 \text { [32] }\end{array}$ & Austria & 308 & $\begin{array}{l}\text { Medical } \\
\text { University } \\
\text { Vienna }\end{array}$ & - & - & - & - & - & - \\
\hline $\begin{array}{l}\text { Parmar V, } \\
2006 \text { [22] }\end{array}$ & India & 664 & $\begin{array}{l}\text { Tata Memorial } \\
\text { Hospital }\end{array}$ & 47.6 & - & 7.4 & $\begin{array}{l}\text { BCS: } 1.5 \\
\text { M: } 4.1\end{array}$ & - & $\begin{array}{l}\text { supraclavicular } \\
\text { lymph node } \\
\text { presented: } 15 \%\end{array}$ \\
\hline $\begin{array}{l}\text { Rouzier R, } \\
\quad 2006 \text { [33] }\end{array}$ & France & 594 & $\begin{array}{l}\text { Institut Gustave } \\
\text { Roussy }\end{array}$ & 50 & $\begin{array}{l}\text { ductal: } 89 \\
\text { lobular: } 11\end{array}$ & 4.9 & 3.1 & $\begin{array}{l}\text { BCS: } \\
\text { I-II: } 43.4 \\
\text { III: } 38 \\
\text { M: } \\
\text { II: } 29.7 \\
\text { III: } 70.3\end{array}$ & $\begin{array}{l}\text { BCS: } 54.4 \\
\text { M: } 56.0\end{array}$ \\
\hline $\begin{array}{l}\text { Shin HC, } \\
2013 \text { [23] }\end{array}$ & Korea & 129 & $\begin{array}{l}\text { Chung-Ang } \\
\text { University } \\
\text { College of } \\
\text { Medicine }\end{array}$ & 45.8 & - & - & - & III & $\begin{array}{l}\text { BCS: } 75.3 \\
\text { M: } 80.8\end{array}$ \\
\hline $\begin{array}{r}\text { Sweeting RS, } \\
2011[24]\end{array}$ & USA & 122 & $\begin{array}{l}\text { University of } \\
\text { North Carolina } \\
\text { School of } \\
\text { Medicine }\end{array}$ & 39.5 & - & $\begin{array}{l}\text { BCS: } 5.6 \\
\text { M: } 6.7\end{array}$ & $\begin{array}{l}\text { BCS: } 1.3 \\
\text { M: } 3.2\end{array}$ & $\begin{array}{l}\text { BCS: } \\
\text { I: } 0 \\
\text { II: } 42 \\
\text { III: } 58 \\
\text { M: } \\
\text { I: } 3 \\
\text { II: } 29 \\
\text { III: } 68\end{array}$ & - \\
\hline
\end{tabular}

$\mathrm{NCT}$ = Neoadjuvant chemotherapy; $\mathrm{BCS}$ = breast-conserving surgery; $\mathrm{M}$ = mastectomy.

\section{Materials and Methods}

\section{Search Strategy}

PubMed, Web of Knowledge, and Ovid's database were searched for the period of January 2000 to June 2015 without language restrictions. The search terms used were 'neoadjuvant chemotherapy', 'locally advanced breast cancer', 'breast-conserving surgery', and 'mastectomy'. The reference lists of relevant studies were checked manually to locate any studies that may have been missed.

\section{Study Selection}

Identified studies were assessed for eligibility for inclusion in the meta-analysis by scrutinizing the titles, abstracts, and keywords of every record retrieved. Studies were restricted to those published in English and Chinese. Clinical studies concerning comparisons of recurrence between BCS and mastectomy following NCT for LABC were also included. 
Data Extraction

Two coauthors (LY and ZX) independently selected studies for inclusion and exclusion and reached a consensus when they did not agree on the initial assignment. The following variables were recorded: authors, journal and year of publication, number of patients, age, and local recurrence rate. If necessary, the corresponding authors of the studies were contacted to obtain additional information.

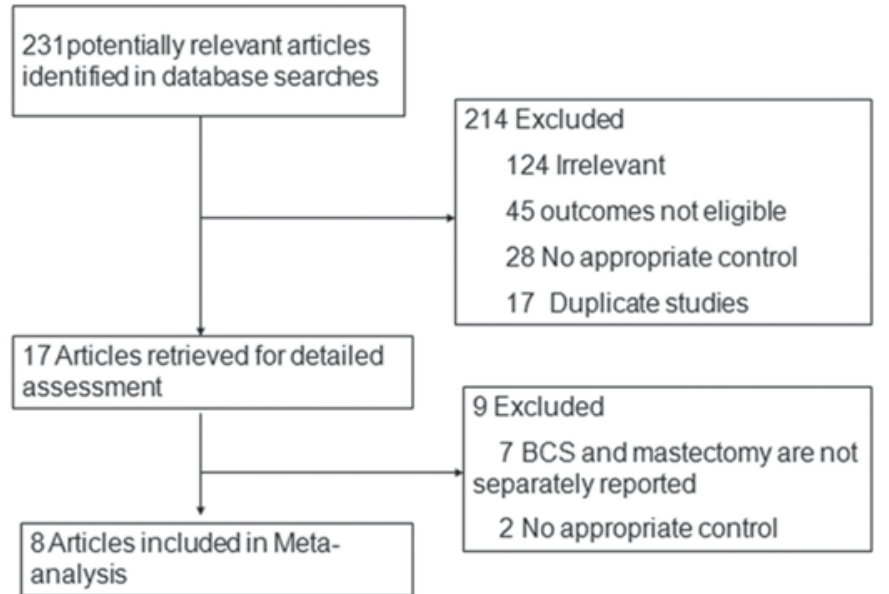

Fig. 1. Flowchart of the results of the literature search.
Statistical Analysis

Pooled estimates of outcome were calculated using a fixed effects model, or a random effects model was used according to the degree of heterogeneity. The test of homogeneity of effects was performed using the $\chi^{2}$ tests, with $p \leq 0.05$ indicating significant heterogeneity. When the hypothesis of homogeneity was not rejected, the fixed effects model was used to estimate the pooled effect of outcomes; when the reverse was true, the random effects model was also calculated. Statistical analyses were carried out using Cochrane Review Manager 5.0 software (Cochrane Collaboration, Freiburg, Germany).

\section{Results}

\section{Study Selection}

We identified 231 potentially relevant articles (fig. 1). After exclusion of duplicate references, nonrelevant literature, and studies that did not satisfy the inclusion criteria, 17 candidate articles were considered for the meta-analysis. After careful review of the full text of these articles, 8 studies were included. The study characteristics are summarized in tables $1-4$.

All papers were retrospective chart reviews. Patient demographics for the 8 studies are presented in table 1 . The publication dates ranged from January 2000 to June 2015. Study size ranged from 122 to 815 patients.

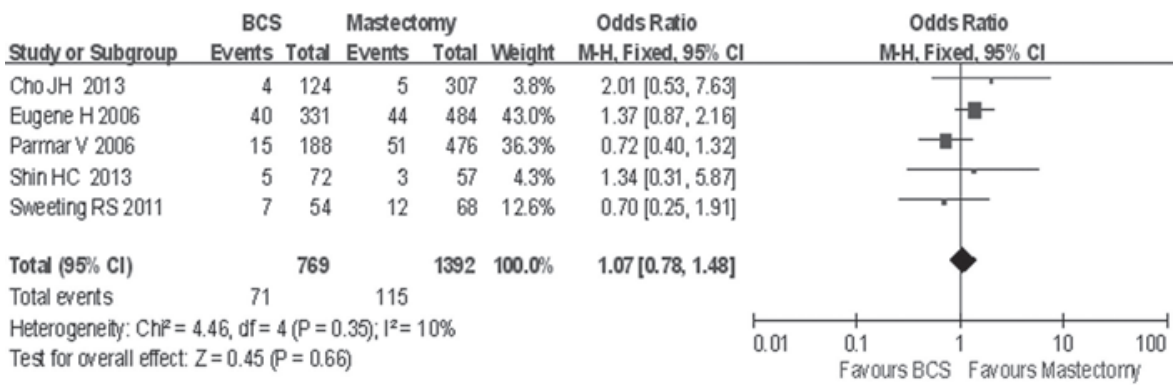

Fig. 2. Forest plot of the comparison of recurrence rates for BCS vs. mastectomy.

\begin{tabular}{|c|c|c|c|c|c|c|c|}
\hline $\begin{array}{l}\text { Author, year } \\
\text { [ref.] }\end{array}$ & $\begin{array}{l}\text { ER-positive, } \\
\%\end{array}$ & $\begin{array}{l}\text { PR-positive, } \\
\%\end{array}$ & $\begin{array}{l}\text { HER2- } \\
\text { positive, \% }\end{array}$ & $\begin{array}{l}\text { NCT responders } \\
\mathrm{CR}+\mathrm{PR}, \%\end{array}$ & $\begin{array}{l}\text { Endocrine } \\
\text { therapy } \\
\text { received, \% }\end{array}$ & $\begin{array}{l}\text { Radiation } \\
\text { received, \% }\end{array}$ & $\begin{array}{l}\text { Median follow- } \\
\text { up, months }\end{array}$ \\
\hline $\begin{array}{l}\text { Cho JH, } \\
2013 \text { [29] }\end{array}$ & $\begin{array}{l}\text { BCS: } 38.7 \\
\text { M: } 55.7\end{array}$ & $\begin{array}{l}\text { BCS: } 33.9 \\
\text { M: } 46.7\end{array}$ & $\begin{array}{l}\text { BCS: } 31.5 \\
\text { M: } 33.0\end{array}$ & $16.7(\mathrm{CR})$ & $\begin{array}{l}\text { BCS: } 45.2 \\
\text { M: } 59.9\end{array}$ & - & 45.9 \\
\hline $\begin{array}{l}\text { Debled M, } \\
2015[30]\end{array}$ & - & - & - & - & - & - & 46.5 \\
\hline $\begin{array}{l}\text { Eugene } \mathrm{H}, \\
2006 \text { [31] }\end{array}$ & - & - & - & $\begin{array}{l}\text { BCS: } 45.2 \\
\text { M: } 54.1\end{array}$ & $\begin{array}{l}\text { BCS: } 39 \\
\text { M: } 32\end{array}$ & $\begin{array}{l}\text { BCS: } 100 \\
\text { M: } 0\end{array}$ & $\begin{array}{l}\text { BCS: } 60 \\
\text { M: } 76\end{array}$ \\
\hline $\begin{array}{l}\text { Fitzal F, } \\
\quad 2010 \text { [32] }\end{array}$ & - & - & - & - & - & - & 60 \\
\hline $\begin{array}{l}\text { Parmar V, } \\
2006 \text { [22] }\end{array}$ & $\begin{array}{l}\text { BCS: } 22.9 \\
\text { M: } 25.4\end{array}$ & $\begin{array}{l}\text { BCS: } 33.5 \\
\text { M: } 30.7\end{array}$ & - & $\begin{array}{l}\text { BCS: } 92.7 \\
\text { M: } 67.1\end{array}$ & - & - & 30 \\
\hline $\begin{array}{l}\text { Rouzier R, } \\
2006 \text { [33] }\end{array}$ & 61 & 54 & - & $\begin{array}{l}\text { BCS: } 74.2 \\
\text { M: } 38.1\end{array}$ & - & - & 67 \\
\hline $\begin{array}{l}\text { Shin HC, } \\
2013 \text { [23] }\end{array}$ & $\begin{array}{l}\text { BCS: } 48.6 \\
\text { M: } 52.6\end{array}$ & - & $\begin{array}{l}\text { BCS: } 27.8 \\
\text { M: } 28.1\end{array}$ & - & - & $\begin{array}{l}\text { BCS: } 100 \\
\text { M: } 100\end{array}$ & 62.4 \\
\hline $\begin{array}{r}\text { Sweeting RS, } \\
2011 \text { [24] }\end{array}$ & $\begin{array}{l}\text { BCS: } 42 \\
\text { M: } 49\end{array}$ & $\begin{array}{l}\text { BCS: } 40 \\
\text { M: } 45\end{array}$ & $\begin{array}{l}\text { BCS: } 27 \\
\text { M: } 33\end{array}$ & 87 & $\begin{array}{l}\text { BCS: } 33 \\
\text { M: } 57\end{array}$ & $\begin{array}{l}\text { BCS: } 98 \\
\text { M: } 78\end{array}$ & 76.8 \\
\hline
\end{tabular}

$\mathrm{ER}=$ Estrogen receptor; $\mathrm{PR}$ = progesterone receptor; HER2 = human epidermal growth factor; $\mathrm{NCT}$ = neoadjuvant chemotherapy; $\mathrm{CR}=$ complete response; $\mathrm{PR}=$ partial response; $\mathrm{BCS}=$ breast-conserving surgery; $\mathrm{M}=$ mastectomy. 
Table 3. Overview of the reviewed studies: inclusion and exclusion criteria

Fig. 3. Forest plot of the comparison of 5-year local recurrence-free survival rates for BCS vs. mastectomy.

Fig. 4. Forest plot of the comparison of 5-year overall survival rates for BCS vs. mastectomy.

\begin{tabular}{|c|c|c|}
\hline Author, year [ref.] & Inclusion criteria & Exclusion criteria \\
\hline Cho JH, 2013 [29] & - & $\begin{array}{l}\text { stage IV disease at diagnosis, bilateral } \\
\text { breast cancers, data on type of surgery } \\
\text { or radiotherapy unavailable, pathologic } \\
\text { tumor size }>3 \mathrm{~cm} \text {, and nonepithelial } \\
\text { origin or special type tumors }\end{array}$ \\
\hline Debled M, 2015 [30] & $\begin{array}{l}\text { HER2-positive, T2-T4 breast } \\
\text { cancer }\end{array}$ & distant metastasis \\
\hline Eugene H, 2006 [31] & - & distant metastasis \\
\hline Fitzal F, 2010 [32] & - & $\begin{array}{l}\text { metastatic breast cancer, inflammatory } \\
\text { breast cancer, infiltration of the thoracic } \\
\text { wall, ECOG }>2 \text {, bilateral breast cancer, } \\
\text { any previous malignancy treated with } \\
\text { curative intent and no freedom from } \\
\text { disease for } 5 \text { years, any recurrent cancer } \\
\text { disease, pregnant or lactating women }\end{array}$ \\
\hline Parmar V, 2006 [22] & $\begin{array}{l}\text { all patients underwent an ini- } \\
\text { tial incision biopsy for tissue } \\
\text { diagnosis, receptor study, } \\
\text { and quadrant localization }\end{array}$ & distant metastasis \\
\hline Rouzier R, 2006 [33] & - & $\begin{array}{l}\text { inflammatory, bilateral, } \mathrm{T} 4 \text {, and } \\
\text { metastatic tumors }\end{array}$ \\
\hline Shin HC, 2013 [23] & $\begin{array}{l}\text { clinical stage III breast cancer } \\
\text { patients }\end{array}$ & inflammatory breast cancer \\
\hline Sweeting RS, 2011 [24] & - & $\begin{array}{l}\text { stage IV disease, inflammatory breast } \\
\text { cancer }\end{array}$ \\
\hline
\end{tabular}

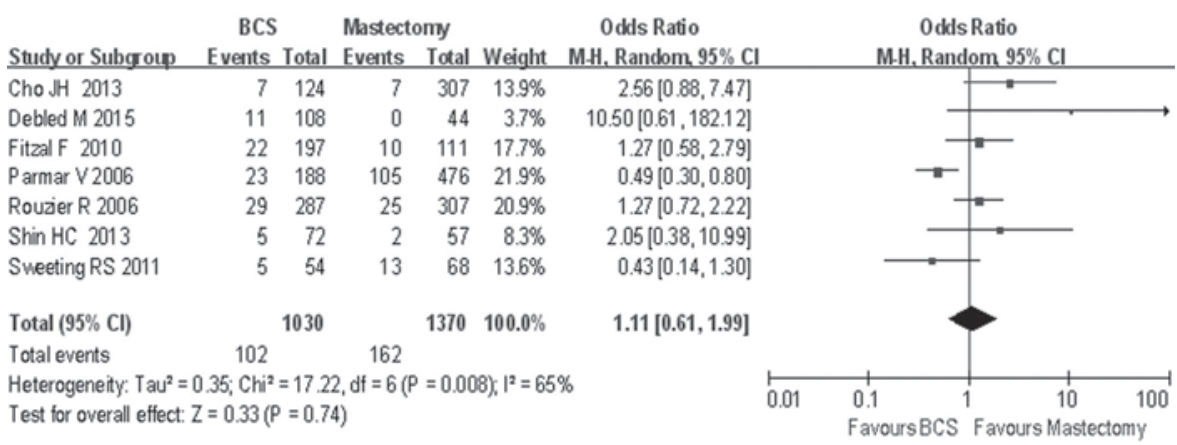

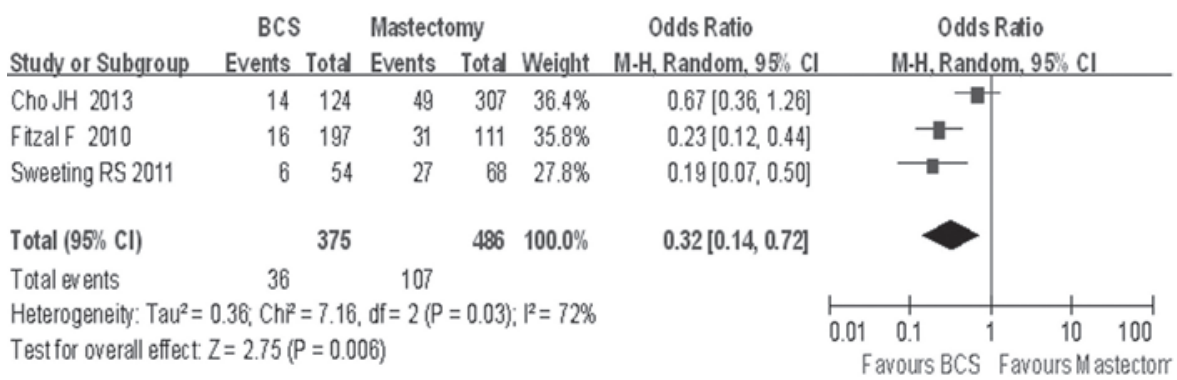

\section{Outcome Measures}

A total of 1,361 patients who underwent BCS and 1,854 patients who underwent mastectomy were analyzed. All patients in the included studies underwent NCT following the diagnosis of cancer.

Five included studies assessed patients for local recurrence. The prevalence of local recurrence was $9.2 \%$ in the BCS group versus $8.3 \%$ in the mastectomy group without significant difference (odds ratio (OR) 1.07, 95\% confidence interval (CI) 0.28-1.48; $\mathrm{p}=0.66$ ) (fig. 2). The 5-year local recurrence-free survival rate (LRFS) was lower in the mastectomy group than in the BCS group, but no significant difference was found between the 2 groups (OR 1.11, 95\% CI 0.61-1.99; $\mathrm{p}=0.74$ ) (fig. 3). 5-year OS was generally better for the BCS group compared with the mastectomy group (OR 0.32, 95\% CI 0.14-0.72; $\mathrm{p}=0.006$ ) (fig. 4). 
Table 4. Overview of the reviewed studies: applied treatments

\begin{tabular}{|c|c|c|c|c|c|}
\hline $\begin{array}{l}\text { Author, } \\
\text { Year [ref.] }\end{array}$ & Kind and duration of NCT & $\begin{array}{l}\text { Kind and duration of } \\
\text { adjuvant chemotherapy }\end{array}$ & $\begin{array}{l}\text { Radiation to breast and/or } \\
\text { regional lymph nodes }\end{array}$ & $\begin{array}{l}\text { Endocrine } \\
\text { treatment }\end{array}$ & $\begin{array}{l}\text { 5-year overall } \\
\text { survival }\end{array}$ \\
\hline $\begin{array}{l}\text { Cho JH, } 2013 \\
\text { [29] }\end{array}$ & $\begin{array}{l}\text { NCT groups received } 3-8 \text { cycles of neo- } \\
\text { adjuvant anthracycline and/or taxane }\end{array}$ & - & $\begin{array}{l}\text { adjuvant radiotherapy } \\
\text { with a median boost dose } \\
\text { of } 10 \text { Gy covering the } \\
\text { whole breast with or with- } \\
\text { out regional nodal area }\end{array}$ & $\begin{array}{l}\text { using selective estro- } \\
\text { gen receptor modula- } \\
\text { tors (SERMs) or aro- } \\
\text { matase inhibitors(AIs) }\end{array}$ & $\begin{array}{l}\text { BCS: } 89.1 \% \\
\text { M: } 84.2 \%\end{array}$ \\
\hline $\begin{array}{l}\text { Debled M, } \\
2015[30]\end{array}$ & trastuzumab-based NCT & $\begin{array}{l}\text { no patient received adjuvant } \\
\text { chemotherapy }\end{array}$ & - & $\begin{array}{l}\text { no patient received en- } \\
\text { docrine treatment }\end{array}$ & - \\
\hline $\begin{array}{l}\text { Eugene H, } \\
2006[31]\end{array}$ & $\begin{array}{l}\text { patients received } 1 \text { of the following } \\
\text { combinations of chemotherapy: } 5 \text {-FU, } \\
\text { doxorubicin, cyclophosphamide(FAC); } \\
\text { vincristine, doxorubicin, cyclophospha- } \\
\text { mide, prednisone (VACP); or doxoru- } \\
\text { bicin and docetaxel (AT) }\end{array}$ & $\begin{array}{l}\text { adjuvant chemotherapy was } \\
\text { given after surgery and before ra- } \\
\text { diation in } 254(77 \%) \text { of the BCS } \\
\text { patients and } 460(95 \%) \text { of the } \\
\text { mastectomy patients }\end{array}$ & $\begin{array}{l}50 \text { Gy delivered in } 25 \text { frac- } \\
\text { tions to the breast or chest } \\
\text { wall tangential fields, fol- } \\
\text { lowed by a } 10 \text {-Gy boost to } \\
\text { the tumor bed or chest } \\
\text { wall scar using an apposi- } \\
\text { tional electron field }\end{array}$ & $\begin{array}{l}\text { tamoxifen was used by } \\
129(39 \%) \text { of the BCS } \\
\text { patients and } 154(32 \%) \\
\text { of the mastectomy pa- } \\
\text { tients }\end{array}$ & $\begin{array}{l}\text { BCS: } 86 \% \\
\text { M: } 59 \%\end{array}$ \\
\hline $\begin{array}{l}\text { Fitzal F, } 2010 \\
\qquad[32]\end{array}$ & $\begin{array}{l}\text { ABCSG; trials ABCSG-7, } \\
\text { ABCSG-14 and ABCSG-24 }\end{array}$ & - & - & - & $\begin{array}{l}\text { BCS: } 81 \% \\
\text { M: } 58 \%\end{array}$ \\
\hline $\begin{array}{l}\text { Parmar V, } \\
2006[22]\end{array}$ & $\begin{array}{l}\text { cyclophosphamide } 500 \mathrm{mg} / \mathrm{m} 2 \text {, anthra- } \\
\text { cycline (adriamycin } 50 \mathrm{mg} / \mathrm{m} 2 \text { or epiru- } \\
\text { bicin } 90 \mathrm{mg} / \mathrm{m} 2 \text { ), and } 5 \text {-FU } 500 \mathrm{mg} / \mathrm{m} 2 \\
\text { ( } 2-6 \text { cycles) until maximum clinical re- } \\
\text { sponse }\end{array}$ & $\begin{array}{l}\text { completion of remaining chemo- } \\
\text { therapy (if any) }\end{array}$ & $\begin{array}{l}\text { sequential radiotherapy } \\
\text { (chest wall and supraclav- } \\
\text { icular fossa) }\end{array}$ & $\begin{array}{l}\text { tamoxifen } 20 \mathrm{mg} / \mathrm{day} \\
\text { after chemotherapy if } \\
\text { the tumor was ER- } \\
\text { and/or PR-positive }\end{array}$ & - \\
\hline $\begin{array}{l}\text { Rouzier R, } \\
2006[33]\end{array}$ & $\begin{array}{l}206(35 \%) \text { patients received AVCMF } \\
\text { (doxorubicin } 50 \mathrm{mg} / \mathrm{m} 2 \text {, vincristine } 1 \\
\mathrm{mg} / \mathrm{m} 2 \text {, cyclophosphamide } 600 \mathrm{mg} / \mathrm{m} 2 \text {, } \\
\text { methotrexate } 30 \mathrm{mg} / \mathrm{m} 2 \text {, and } 5 \text {-FU } 900 \\
\mathrm{mg} / \mathrm{m} 2 \text { ); } 22(4 \%) \text { and } 170(28 \% \text { ) pa- } \\
\text { tients received FAC } 50 / \text { FEC } 50-60 \\
\text { (doxorubicin } 50 \mathrm{mg} / \mathrm{m} 2 \text {, epirubicin } \\
50 / 60 \mathrm{mg} / \mathrm{m} 2 \text {, cyclophosphamide } 600 \\
\mathrm{mg} / \mathrm{m} 2 \text {, and } 5 \text {-FU } 900 \mathrm{mg} / \\
\mathrm{m} 2 \text { ),respectively; and } 196(33 \%) \text { pa- } \\
\text { tients received FEC } 100 \text { (epirubicin } 100 \\
\mathrm{mg} / \mathrm{m} 2 \text {, cyclophosphamide } 1,000 \mathrm{mg} / \\
\mathrm{m} 2 \text {, and } 5 \text {-FU } 1000 \mathrm{mg} / \mathrm{m} 2 \text { ). } \\
3 \text { or } 4 \text { cycles of NCT }\end{array}$ & $\begin{array}{l}2 \text { or } 3 \text { cycles of FAC } 50 \text { or FEC } \\
50 / 60 / 100\end{array}$ & $\begin{array}{l}\text { postoperative radiother- } \\
\text { apy to the breast ( } 45 \mathrm{~Gy})\end{array}$ & $\begin{array}{l}\text { tamoxifen } 20 \mathrm{mg} \text { per } \\
\text { day was prescribed for } \\
\text { all postmenopausal } \\
\text { patients and for pre- } \\
\text { menopausal patients } \\
\text { with ER-positive tu- } \\
\text { mors }\end{array}$ & - \\
\hline $\begin{array}{l}\text { Shin HC, } \\
2013 \text { [23] }\end{array}$ & $\begin{array}{l}158 \text { patients received intravenous adria- } \\
\text { mycin } 50 \mathrm{mg} / \mathrm{m} 2 \text { infused over } 30 \mathrm{~min} \text {, } \\
\text { followed by docetaxel } 75 \mathrm{mg} / \mathrm{m} 2 \text { over } 1 \\
\text { h every } 3 \text { weeks for } 3 \text { cycles; } 6 \text { patients } \\
\text { received intravenous adriamycin } 60 \mathrm{mg} / \\
\mathrm{m} 2 \text { over } 30 \mathrm{~min} \text { and cyclophosphamide } \\
600 \mathrm{mg} / \mathrm{m} 2 \text { over } 30 \mathrm{~min}(\mathrm{AC} \text { ) every } 3 \\
\text { weeks for } 3 \text { or } 4 \text { cycles; } 2 \text { patients re- } \\
\text { ceived intravenous } 5 \text {-FU } 500 \mathrm{mg} / \mathrm{m} 2 \text {, } \\
\text { epirubicin } 100 \mathrm{mg} / \mathrm{m} 2 \text {, and cyclophos- } \\
\text { phamide } 500 \mathrm{mg} / \mathrm{m} 2 \text { (FEC) every } 3 \\
\text { weeks for } 3 \text { cycles }\end{array}$ & $\begin{array}{l}\text { given to patients who received } 3 \\
\text { cycles of neoadjuvant docetaxel } \\
\text { in the NCT group; } 3 \text { additional } \\
\text { cycles of DA offered after surgery } \\
168 \text { patients in the surgery group: } \\
\text { adriamycin } 60 \mathrm{mg} / \mathrm{m} 2 \text { and cyclo- } \\
\text { phosphamide } 600 \mathrm{mg} / \mathrm{m} 2 \text { infused } \\
\text { over } 30 \text { min every } 3 \text { weeks for } 4 \\
\text { cycles followed by docetaxel } 75 \\
\text { mg/m } 2 \text { over } 1 \text { h every } 3 \text { weeks for } \\
4 \text { cycles after surgery; the remain- } \\
\text { ing } 25 \text { patients in the surgery } \\
\text { group received adriamycin }+ \text { cy- } \\
\text { clophosphamide +methotrexate } \\
+5 \text {-FU, or } 5 \text {-FU +adriamycin } \\
+ \text { cyclophosphamide }\end{array}$ & $\begin{array}{l}\text { all patients received radia- } \\
\text { tion therapy to the entire } \\
\text { breast ( } 50.4 \text { Gy in } 28 \text { ses- } \\
\text { sions over a } 5-6 \text { week pe- } \\
\text { riod) with additional boost } \\
\text { radiation ( } 9-10 \mathrm{~Gy} \text { ) to the } \\
\text { tumor bed } \\
\text { axillary and supraclavicu- } \\
\text { lar radiation ( } 50.4 \mathrm{~Gy} \text { ) was } \\
\text { performed on patients } \\
\text { with clinical N2 stage or } \\
\text { higher regardless of the } \\
\text { pathologic } \mathrm{N} \text { stage in the } \\
\text { NCT group }\end{array}$ & - & - \\
\hline $\begin{array}{l}\text { Sweeting RS, } \\
2011[24]\end{array}$ & $\begin{array}{l}97 \% \text { of patients underwent a regimen } \\
\text { that included an anthracycline and } 69 \% \\
\text { of patients underwent a regimen that } \\
\text { included a taxane }\end{array}$ & - & $\begin{array}{l}\text { majority of patients re- } \\
\text { ceived adjuvant radiation } \\
(87 \%)\end{array}$ & $\begin{array}{l}\text { of the } 25 \text { patients who } \\
\text { were HER2-positive, } \\
40 \% \text { received trastu- } \\
\text { zumab; } 57(47 \%) \text { pa- } \\
\text { tients received endo- } \\
\text { crine therapy }\end{array}$ & $\begin{array}{l}\text { BCS: } 83.0 \% \\
\text { M: } 68.0 \%\end{array}$ \\
\hline
\end{tabular}

NCT = Neoadjuvant chemotherapy; BCS = breast-conserving surgery; $\mathrm{M}=$ mastectomy; 5-FU = 5-fluorouracil; FAC = 5-FU+doxorubicin+cyclophosphamide; $\mathrm{FEC}=5$-FU+epirubicin+cyclophosphamide; $\mathrm{ER}=$ estrogen receptor; $\mathrm{PR}=$ progesterone receptor. 


\section{Discussion}

It is well known that NCT can efficaciously downstage the primary tumor. For patients with large tumors warranting mastectomy at the initial diagnosis, the use of NCT has been shown to downsize the primary tumor and make BCS possible $[14,15]$. In 2006, Rouzier et al. [16] developed a nomogram for breast cancer patients who receive NCT to predict residual tumor size and whether the patients could become eligible for BCS following anthracycline-based or paclitaxel-based chemotherapy.

In our study, we investigated local recurrence rates after BCS compared with mastectomy in LABC patients having received NCT. The main challenge for patients with LABC treated with BCS after NCT is to show an acceptable local recurrence rate compared to those treated with mastectomy. There are concerns that advanced primary tumors treated with BCS may have higher local recurrence rates than those treated with mastectomy after NCT because tumors treated with NCT may dwindle into multicentric fragments such as honeycombs. This response is the main barrier to applying routine BCS in patients receiving NCT due to the difficulty of assessing surgical margins accurately [17]. The oncologic safety of BCS after NCT in patients with an initial diagnosis of LABC has been investigated in previous studies. The NSABP-B18 trial demonstrated higher LRFS in the NCT-BCS group compared with the NCT-mastectomy group [4]. However, after adjusting for patient age and clinical tumor size, that difference was no longer significant [18]. Another study also failed to show a significant difference in LRFS between NCT-BCS and NCT-mastectomy patients [19]. The study by Ishitobi et al. [2] also found no significant difference in LRFS according to type of surgery after NCT in patients with a planned mastectomy at the initial exam. This is in concordance with our finding that BCS after NCT does not significantly increase the risk of LRFS compared to mastectomy (fig. 3). Hence, the current study suggests that BCS after NCT in LABC patients is a safe alternative to mastectomy.

Previous studies $[20,21]$ demonstrated that OS rates were not statistically different between the BCS group and the mastectomy group. However, our meta-analysis indicated that 5-year OS rates were improved for women who were able to undergo BCS after NCT as compared with those who underwent mastectomy, suggesting that being a candidate for BCS after NCT may be a proxy for tumor biology.

Three studies [22-24] supported the concept that BCS after NCT in patients with large primary breast tumors could be a reasonable treatment option if the tumor size decreased to $\leq 4 \mathrm{~cm}$ after NCT, regardless of the initial tumor size. However, patients who showed no response to NCT undergoing BCS had a significantly increased local relapse rate compared with mastectomy patients. However, because of significant differences in nodal status, grading, and tumor size between the 2 groups, the results have to be viewed with caution.

Several studies [25-27] showed that the local recurrence rate for patients with advanced breast cancer was significantly reduced by radiation therapy, and the use of radiation therapy was also associated with improved OS [25]. Investigators concluded that radiation therapy provides a significant clinical benefit for breast cancer patients who present with advanced disease and achieve a pathologic complete response after NCT [28]. However, our included studies did not show much information about the efficacy of radiation therapy. The benefit of adjuvant radiotherapy should be further investigated in prospective studies.

In summary, our meta-analysis reviewed much of the relevant literature published to date, and demonstrated that BCS after NCT is a reasonable option for women who respond to NCT. However, this study has several limitations. First, it was a retrospective study and there may be bias in the analysis of the data. Second, the local recurrence rate was low and the follow-up of some studies [22,29] was very short. This may have been a reason why these studies failed to reveal a difference in local recurrence rates between groups. Further research must be performed with adequate reporting of recurrence based on stage and 5-year OS, which would then allow clinicians to better council patients about BCS-NCT for LABC.

\section{Conclusion}

Breast conservation can safely be offered to women with LABC who respond to NCT. Surgery remains an essential part of treatment even in good responders. Responders automatically form a subgroup with better clinical outcome. BCS after NCT is safe in terms of local recurrence and LRFS in women with LABC. Shrinking tumors with NCT provides the opportunity to apply BCS with no detriment to outcome.

\section{Disclosure Statement}

No sponsorship or funding arrangements relating to our research and no conflicts of interest exist.

\section{References}

1 Fitzal F, Mittlboeck M, Steger G, et al.: Neoadjuvant chemotherapy increases the rate of breast conservation in lobular-type breast cancer patients. Ann Surg Oncol 2012;19:519-526.
2 Ishitobi M, Ohsumi S, Inaji $\mathrm{H}$, et al.: Ipsilateral breast tumor recurrence (IBTR) in patients with operable breast cancer who undergo breast-conserving treatment after receiving neoadjuvant chemotherapy: risk factors of IBTR and validation of the MD Anderson Prognostic Index. Cancer 2012;118:4385-4393.
3 Chen S, Chen CM Yu KD, et al.: A prognostic model to predict outcome of patients failing to achieve pathological complete response after anthracycline-containing neoadjuvant chemotherapy for breast cancer. J Surg Oncol 2012;105:577-585. 
4 Wolmark N, Wang J, Mamounas E, Bryant J, Fisher B Preoperative chemotherapy in patients with operable breast cancer: nine-year results from National Surgical Adjuvant Breast and Bowel Project B-18. J Natl Cancer Inst Monogr 2001;30:96-102.

5 Van der Hage JA, van de Velde CJ, Julien JP, TubianaHulin M, Vandervelden C, Duchateau L: Preoperative chemotherapy in primary operable breast cancer: results from the European Organization for Research and Treatment of Cancer trial 10902. J Clin Oncol 2001;19:4224-4237.

6 Chen AM, Meric-Bernstam F, Hunt KK, et al.: Breast conservation after neoadjuvant chemotherapy: the MD Anderson cancer center experience. J Clin Oncol 2004; 22:2303-2312

7 Makris A, Powles TJ, Ashley SE, et al.: A reduction in the requirements for mastectomy in a randomized trial of neoadjuvant chemoendocrine therapy in primary breast cancer. Ann Oncol 1998;9:1179-1184.

8 Singletary SE, McNeese MD, Hortobagyi GN: Feasibility of breast-conservation surgery after induction chemotherapy for locally advanced breast carcinoma. Cancer 1992;69:2849-2852.

9 Cance WG, Carey LA, Calvo BF, et al.: Long-term outcome of neoadjuvant therapy for locally advanced breast carcinoma: effective clinical downstaging allows breast preservation and predicts outstanding local control and survival. Ann Surg 2002;236:295-303.

10 Chen AM, Meric-Bernstam F, Hunt KK, et al.: Breast conservation after neoadjuvant chemotherapy: the $\mathrm{M}$. D. Anderson Cancer Center Experience. J Clin Oncol 2004;22:2303-2312.

11 Kuerer HM, Newman LA, Smith TL, et al.: Clinical course of breast cancer patients with complete pathologic primary tumor and axillary lymph node response to doxorubicin-based neoadjuvant chemotherapy. J Clin Oncol 1999;17:460-469.

12 Mauriac L, MacGrogan G, Avril A, et al.: Neoadjuvant chemotherapy for operable breast carcinoma larger than $3 \mathrm{~cm}$ : a unicentre randomized trial with a 124 month median follow up. Ann Oncol 1999;10:47-52.

13 Rouzier R, Extra JM, Carton M, et al.: Primary chemotherapy for operable breast cancer: incidence and prognostic significance of ipsilateral breast tumor recurrence after breast-conserving surgery. J Clin Oncol 2001;19:3828-3835.
14 Kuerer HM, Singletary SE, Buzdar AU, et al.: Surgical conservation planning after neoadjuvant chemotherapy for stage II and operable stage III breast carcinoma. Am J Surg 2001;182:601-608.

15 Vlastos G, Mirza NQ, Lenert JT, et al.: The feasibility of minimally invasive surgery for stage IIA, IIB, and IIIA breast carcinoma patients after tumor downstaging with induction chemotherapy. Cancer 2000;88:1417-1424.

16 Rouzier R, Pusztai L, Garbay JR, et al.: Development and validation of nomograms for predicting residual tumor size and the probability of successful conservative surgery with neoadjuvant chemotherapy for breast cancer. Cancer 2006;107:1459-1466.

17 Chawla A, Hunt KK, Mittendorf EA: Surgical considerations in patients receiving neoadjuvant systemic therapy. Future Oncol 2012;8:239-250.

18 Rastogi P, Anderson SJ, Bear HD, et al.: Preoperative chemotherapy: updates of national surgical adjuvant breast and bowel project protocols B-18 and B-27. J Clin Oncol 2008;26:778-785.

19 Touboul E, Lefranc JP, Blondon J, et al.: Primary chemotherapy and preoperative irradiation for patients with stage II larger than $3 \mathrm{~cm}$ or locally advanced non-inflammatory breast cancer. Radiother Oncol 1997;42:219-229.

20 Barranger E, Antomarchi J, Chamorey E, et al.: Effect of neoadjuvant chemotherapy on the surgical treatment of patients with locally advanced breast cancer requiring initial mastectomy. Clin Breast Cancer 2015; 15:e231-235

21 Levy A, Borget I, Bahri M, et al.: Loco-regional control after neo-adjuvant chemotherapy and conservative treatment for locally advanced breast cancer patients. Breast J 2014;20:381-387.

22 Parmar V, Krishnamurthy A, Hawaldar R, et al.: Breast conservation treatment in women with locally advanced breast cancer - experience from a single centre. Int J Surg 2006;4:106-114.

23 Shin HC, Han W, Moon HG, et al.: Breast-conserving surgery after tumor downstaging by neoadjuvant chemotherapy is oncologically safe for stage III breast cancer patients. Ann Surg Oncol 2013;20:2582-2589.

24 Sweeting RS, Klauber-Demore N, Meyers MO, et al.: Young women with locally advanced breast cancer who achieve breast conservation after neoadjuvant chemotherapy have a low local recurrence rate. Am Surg 2011;77:850-855
25 McGuire SE, Gonzalez-Angulo AM, Huang EH, et al.: Postmastectomy radiation improves the outcome of patients with locally advanced breast cancer who achieve a pathologic complete response to neoadjuvant chemotherapy. Int J Radiat Oncol Biol Phys 2007;68: 1004-1009.

26 Nagar H, Mittendorf EA, Strom EA, et al.: Local-regional recurrence with and without radiation therapy after neoadjuvant chemotherapy and mastectomy for clinically staged T3N0 breast cancer. Int J Radiat Oncol Biol Phys 2011;81:782-787.

27 Huang EH, Tucker SL, Strom EA, et al.: Postmastectomy radiation improves local-regional control and survival for selected patients with locally advanced breast cancer treated with neoadjuvant chemotherapy and mastectomy. J Clin Oncol 2004;22:4691-4699.

28 Akyurek S, Yavas G: Role of postmastectomy radiation therapy after neoadjuvant chemotherapy in locally advanced breast cancer. Exp Oncol 2013;35:267-271.

29 Cho JH, Park JM, Park HS, Park S, Kim SI, Park BW: Oncologic safety of breast-conserving surgery compared to mastectomy in patients receiving neoadjuvant chemotherapy for locally advanced breast cancer. J Surg Oncol 2013;108:531-536.

30 Debled M, MacGrogan G, Breton-Callu C, et al.: Surgery following neoadjuvant chemotherapy for HER2positive locally advanced breast cancer. Time to reconsider the standard attitude. Eur J Cancer 2015;51:697704.

31 Huang EH, Strom EA, Perkins GH, et al.: Comparison of risk of local-regional recurrence after mastectomy or breast conservation therapy for patients treated with neoadjuvant chemotherapy and radiation stratified according to a prognostic index score. Int J Radiat Oncol Biol Phys 2006;66:352-357.

32 Fitzal F, Riedl O, Mittlböck M, et al.: Oncologic safety of breast conserving surgery after tumour downsizing by neoadjuvant therapy: a retrospective single centre cohort study. Breast Cancer Res Treat 2011;127:121128.

33 Rouzier R, Mathieu MC, Sideris L, et al.: Breast-conserving surgery after neoadjuvant anthracycline-based chemotherapy for large breast tumors. Cancer 2004 101:918-925. 